\title{
An Analysis of Financial Impact of Coronavirus Disease 2019 Pandemic among People in Indonesia: A Case of Health Personnel
}

\author{
Ingenida Hadning* (D, N. Qurrotu’ Ainii \\ School of Pharmacy, Faculty of Medicine and Health Sciences, Universitas Muhammadiyah Yogyakarta, Yogyakarta, Indonesia
}

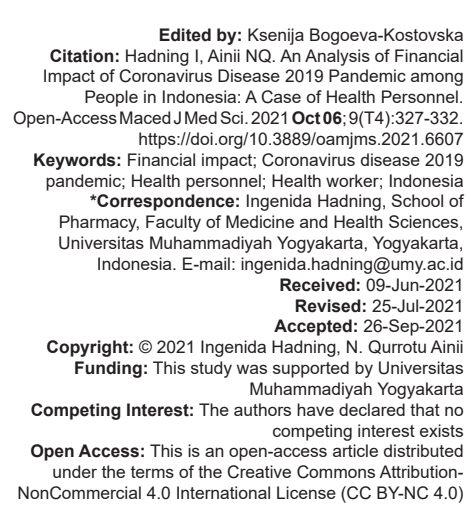

Introduction

In December 2019, there was an outbreak of pneumonia with an unknown cause in Wuhan, China. After conducting some research, it resulted in the isolation of a novel coronavirus, severe acute respiratory syndrome coronavirus 2 (SARS-CoV-2), which was later called coronavirus disease 2019 (COVID-19) by the World Health Organization (WHO) in February 2020 [1]. The fatal consequence of SARS-CoV-2 infection is mortality. The incidence of SARS-CoV-2 infection has spread widely almost all over the world. Based on the WHO data as of August 13, 2020, 20,439,814 cases were confirmed of COVID-19 worldwide with a death rate of $3.64 \%$. Data on confirmed cases of COVID-19 in Indonesia totaled 132,816 as of May 31, 2020, with a death rate of $5.97 \%$ [2].

Compared to seasonal flu, COVID-19 is twice contagious and has a long incubation period for symptoms to appear. Besides, people who feel healthy can "carry" the virus without them knowing it. The Centers for Disease Control and Prevention and
Other stated that everyone has $60-80 \%$ chance of contracting COVID-19, and this virus has the potential to kill millions of people [3]. Therefore, it is necessary to take steps to prevent disease transmission and avoid the worst scenario.

Public health experts believe that each individual's behaviors are essential to control the spread of COVID-19 [4]. The expected behaviors are the habit of washing hands regularly and adequately, avoiding gatherings or groups, canceling traveling plans, and maintaining sufficient distance from other people [3]. According to Van Bavel et al., 2020 [1], the COVID-19 pandemic impacted the economy. If the economy did not run normally, it would balance income and expenditure [5]. According to Adityo et al., 2020 [6], health workers were among the populations at high risk of contracting this virus. In addition, health workers must also continue to work in health services with protocols that must be followed. The continuing rise in the number of confirmed cases causes considerable pressure on health-care providers. Health workers who focus on education and research are asked to work in the clinical realm. Practicing doctors are forced to close 
their practices temporarily, and many health workers work beyond their working hours.

It can affect the level of productivity of health workers [7]. Therefore, it is necessary to analyze the financial impact of the COVID-19 pandemic among health workers in Indonesia by calculating daily income costs before and during COVID-19 pandemic and daily expenses before and during COVID-19 pandemic. Researchers would like to identify the financial impact of the COVID-19 pandemic among Indonesia's health workers through this research. Hopefully, this research can bring benefits to various parties as well as materials for the formulation of policies in the future.

\section{Methods}

This research was conducted using the observational research method with a cross-sectional approach technique. The analysis with variable measurement was only done once at a time without any follow-up. Data collection was performed on the calculation of the cost from the community's point of view [8]. This research was conducted from June to August 2020 with the distribution of e-questionnaires throughout Indonesia.

The population in this study was Indonesian health workers. This study's sample was taken using a non-probability sampling technique with a sampling duration of 1 month. In this method, the sample size was the same as the population [9]. This research's inclusion criteria were health workers, males and females, aged 18-65 years, and willing to become respondents. Meanwhile, the exclusion criteria were respondents who did not complete the questionnaire. The independent variable in this study was the amount of income before and during the pandemic and the amount of expenditure before and during the pandemic. The dependent variable was the financial impact.

The instrument for this research was an e-questionnaire distributed through social media. The researchers developed this questionnaire to assess the amount of income both before and during the COVID19 pandemic and the amount of expenditure before and during the COVID-19 pandemic.

Data analysis began by testing the validity and reliability of the questionnaire. A validity test was conducted to measure the validity of a test [10]. The reliability test was used to determine the consistency of measuring instruments, where the measuring instrument had the ability to be relatively consistent if the measurement was repeated [11]. In this study, the validity test was applied to all the questions in the research instrument. The validity test technique used was by correlating the item score with the item total score. The correlation calculation result was in the form of a correlation coefficient, which was then used to measure an item's validity level. The validity test used was the "Pearson Bivariate" correlation test or "Product Moment." The Pearson test was suitable for use in the validity test, whose data were a Likert scale. The validity test was conducted by comparing rcount and rtable. If the results obtained rcount > rtable, it could be said that the item was valid. To obtain rcount, "SPSS" data processing application was used while the minimum rtable was 0.361 [9]. The reliability test was performed using Cronbach's alpha method. This test was conducted by comparing the results of the Cronbach alpha test ( $\alpha$ count) with the minimum Cronbach alpha value (atable). According to Sugiyono, 2020 [9], the minimum Cronbach alpha value was 0.600 . To identify the Cronbach alpha count results, the SPSS application was needed. If the Cronbach alpha count result was more significant than the minimum Cronbach alpha value, the questionnaire could be reliable.

Analysis of the average data was carried out using the descriptive analysis method, which included the exposure of data from the cost of income and expenses before and during the COVID-19 pandemic, then the average was calculated using the SPSS application. Analysis of the average comparison data for both income and expense before and during the COVID-19 pandemic was conducted to calculate the average difference between the two groups (before and during the pandemic). The significance test was then carried out with a statistical analysis method, namely, the "Paired Sample Test" method if the data were normally distributed; or with the "Wilcoxon Signed- Ranks" method if the data were not normally distributed. Comparative analysis of the difference between the average cost of income and expenditure before and during the COVID-19 pandemic was then conducted.

\section{Results}

\section{Validity and reliability}

The validity test of this questionnaire was conducted using the SPSS application for Windows version 20 . The validity test in the study used a $95 \%$ confidence level with a sample of 30 respondents. The test method was the Pearson bivariate test or product moment. The test was continued by comparing the result of $r_{\text {count }}$ and $r_{\text {table }}$. The questionnaire was considered valid if the result was $r_{\text {count }}>r_{\text {table, }}$, where the $r_{\text {table }}$ was 0.361 [9]. The $r_{\text {table }}$ value for the total sample of 30 with a significance level of $5 \%$ was 0.361 . The questionnaire's validity test resulted in $r_{\text {count }}>0.361$ so that all questions had been valid.

The reliability test of the questionnaire was also conducted using the SPSS for Windows 
version 20 . The reliability test method for testing the questionnaire was Cronbach's alpha, with a sample of 30 respondents. The decision-making for the reliability test results was by comparing the test result of Cronbach alpha count $\left(\alpha_{\text {count }}\right)$ and Cronbach alpha table value $\left(\alpha_{\text {table }}\right)$, where the minimum Cronbach alpha value was 0.600 [9]. The questionnaire's reliability test had $\alpha_{\text {count }}$ of $0.814(>0.600)$, indicating that all question items were reliable with the interpretation result of "very strong" or "very reliable."

\section{Respondent characteristics}

In this research, the questionnaire distribution was conducted through social media platforms for 1 month (30 days) by redistributing the questionnaire twice a week. The number of respondents obtained was 184 people who had met this study's inclusion and exclusion criteria. The distribution of the respondents' domicile by province is shown in Table 1.

Table 1: Respondents' characteristics

\begin{tabular}{|c|c|c|}
\hline \multirow[t]{2}{*}{ Categories } & \multicolumn{2}{|c|}{ Quantity } \\
\hline & $\mathrm{n}$ & $\%$ \\
\hline \multicolumn{3}{|l|}{ Respondent domicile distribution } \\
\hline Central Java & 12 & 6.52 \\
\hline Special Region of Yogyakarta & 9 & 4.89 \\
\hline South Borneo & 9 & 4.89 \\
\hline Aceh & 7 & 3.80 \\
\hline East Java & 7 & 3.80 \\
\hline Bengkulu & 6 & 3.26 \\
\hline Banten & 6 & 3.26 \\
\hline Special Capital District of Jakarta & 6 & 3.26 \\
\hline Bali & 6 & 3.26 \\
\hline Gorontalo & 6 & 3.26 \\
\hline Jambi & 5 & 2.72 \\
\hline South Sumatra & 5 & 2.72 \\
\hline Lampung & 5 & 2.72 \\
\hline Bangka Belitung Islands & 4 & 2.17 \\
\hline West Java & 5 & 2.72 \\
\hline West Nusa Tenggara & 5 & 2.72 \\
\hline East Nusa Tenggara & 5 & 2.72 \\
\hline North Kalimantan & 5 & 2.72 \\
\hline Central Kalimantan & 5 & 2.72 \\
\hline East Kalimantan & 5 & 2.72 \\
\hline West Sulawesi & 5 & 2.72 \\
\hline Central Sulawesi & 5 & 2.72 \\
\hline Southeast Sulawesi & 5 & 2.72 \\
\hline North Maluku & 5 & 2.72 \\
\hline Maluku & 5 & 2.72 \\
\hline West Papua & 5 & 2.72 \\
\hline North Sumatra & 4 & 2.17 \\
\hline West Sumatra & 4 & 2.17 \\
\hline Riau & 4 & 2.17 \\
\hline Riau islands & 4 & 2.17 \\
\hline West Kalimantan & 4 & 2.17 \\
\hline North Sulawesi & 4 & 2.17 \\
\hline Papua & 4 & 2.17 \\
\hline South Sulawesi & 3 & 1.63 \\
\hline \multicolumn{3}{|l|}{ Gender distribution } \\
\hline Male & 70 & 38.04 \\
\hline Female & 114 & 61.96 \\
\hline \multicolumn{3}{|l|}{ Distribution of respondents' age } \\
\hline $18-25$ years old & 82 & 44.57 \\
\hline $26-45$ years old & 90 & 48.91 \\
\hline $46-65$ years old & 12 & 6.52 \\
\hline
\end{tabular}

\section{Analysis of financial impact}

The financial impact referring to productivity on Sutrisno, 2009 [12], is a comparison between expenditure and income. The total questions given to the respondents were nine items. Four items were quantitative questions consisting of questions on average income before and during the pandemic, average expenditure before and during the pandemic. While the other five items consisted of questions about income sources before and during the pandemic, changes in dominant expenses, expenses/needs that were difficult to meet during the pandemic, and solutions made to fulfill these needs.

The financial impact of the COVID-19 pandemic among health workers in Indonesia based on their gender and age is shown in Table 2.

Table 2: Analysis of financial impact by gender and age

\begin{tabular}{llll}
\hline Variables & Categories & Mean (IDR) & SD (IDR) \\
\hline Financial impact by gender & & & \\
Income decrease & Male & $1,272,857$ & $2,597,039$ \\
& Female & $1,004,824$ & $2,400,257$ \\
Expenditure increase & Male & $1,242,142$ & 933,112 \\
& Female & $1,084,868$ & $2,224,788$ \\
Financial impact by age & & & \\
Income decrease & 18-25 years old & 676,829 & $1,654,197$ \\
& 26-45 years old & $1,440,555$ & $2,993,784$ \\
Expenditure increase & 46-65 years old & $1,541,666$ & $2,571,330$ \\
& $18-25$ years old & 823,780 & 657,024 \\
& $26-45$ years old & $1,406,388$ & $2,486,349$ \\
& $46-65$ years old & $1,375,000$ & $1,350,504$ \\
\hline
\end{tabular}

The financial impact was analyzed using the descriptive analysis to obtain the mean and standard deviation of each variable in the form of income before and during the pandemic and expenditure before and during the pandemic. The results of the financial impact are shown in Table 3.

Table 3: The financial impact

\begin{tabular}{lll}
\hline Category & Mean (IDR) & SD (IDR) \\
\hline Average income before the pandemic & $15,100,000$ & $10,909,764$ \\
Average income during the pandemic & $13,993,206$ & $10,210,825$ \\
Average expenditure before the pandemic & $4,590,266$ & $3,142,722$ \\
Average expenditure during the pandemic & $5,733,967$ & $4,249,593$ \\
\hline
\end{tabular}

The source of income of respondents both before and during the pandemic had also changed. Details of the respondent's income sources are shown in Table 4.

Table 4: Respondents' income sources

\begin{tabular}{llll}
\hline Income source & Before the pandemic & After the pandemic & Difference \\
\hline Business & 115 & 93 & -22 \\
Practices & 2 & 1 & -1 \\
Parent/guardian allowance & 7 & 8 & +1 \\
Salary & 184 & 184 & 0 \\
Husband's livelihood & 2 & 2 & 0 \\
\hline
\end{tabular}

There had been many price increases during the pandemic, such as prices for primary, secondary, and even tertiary needs. Health workers who continued to open businesses or practices needed to purchase medical devices' necessities to support the COVID-19 health protocol. The dominant expenditure changes in the respondents are shown in Table 5.

Table 5: The dominant changes in respondents' expenditure

\begin{tabular}{lll}
\hline Dominant changes in expenditures & Quantity & $\%$ \\
\hline Health (medicine, vitamins, and sanitation) & 140 & 26.07 \\
Food ingredients (basic food, vegetables, and & 131 & 24.39 \\
raw side dishes) & & \\
Finished food/drink & 107 & 19.93 \\
Phone credit/data package & 87 & 2.23 \\
Electricity & 51 & 9.50 \\
Public transportation & 12 & 16.20 \\
Fuel oils & 9 & 1,67 \\
\hline
\end{tabular}


In addition to the problem of changes in the needs above, respondents also experienced difficulties in fulfilling needs such as credit installment fees, pulses, and others. Details of needs that were difficult to fulfill during the pandemic are shown in Table 6.

Table 6: Expenditures that are difficult to fulfill

\begin{tabular}{lll}
\hline Expenditures that are difficult to fulfill & Quantity & $\%$ \\
\hline Credit installments & 96 & 31.68 \\
Health insurance fee & 70 & 23.10 \\
Cost of education & 34 & 11.22 \\
Employee salary and holiday allowance & 32 & 10.56 \\
None & 29 & 9.57 \\
Phone credit/data package & 24 & 7.92 \\
Company maintenance costs & 16 & 5.28 \\
Medical devices & 2 & 0.66 \\
\hline
\end{tabular}

The solutions made by respondents to fulfill the needs are shown in Table 7.

Table 7: Respondents' solutions for expenditure fulfillment

\begin{tabular}{lll}
\hline Changes & Quantity & $\%$ \\
\hline Not taking any action & 142 & 73.95 \\
Saving Use & 28 & 14.58 \\
Cutting employee salaries & 13 & 6.77 \\
Applying for relaxation of credit payments & 7 & 3.64 \\
Taking a loan & 1 & 0.52 \\
Closing the practice temporarily & 1 & 0.52 \\
\hline
\end{tabular}

\section{Discussion}

\section{Respondent characteristics}

Based on the data in Table 1, the majority of respondents were domiciled in Central Java with a percentage of $6.52 \%$ followed by Special Region of Yogyakarta and South Kalimantan with the same percentage of $4.89 \%$. Meanwhile, the smallest percentage of respondents was domiciled in South Sulawesi. The domicile of respondents was evenly distributed as all provinces were represented.

Based on the data in Table 1, the majority of respondents were female, with a percentage of $61.96 \%$. This difference in distribution could be influenced by women's tendency to have higher social media consumption than men [13]. Moons et al., 2004 in Nofitri, 2009 [14], pointed out that gender was one factor that affected the quality of life. Furthermore, Herawati and Sasana, 2013 [15], stated that gender could affect the level of work productivity.

Based on the data in Table 1, the majority of respondents in this study were in the age range of 26-45 years old, with a percentage of $48.91 \%$. Aulia Nur, 2014 [13], explained that people aged 20-29 years old and 30-39 years old used electronic mass media as their primary information consumption, while people over 40 years old used television as the primary information consumption. The working age allowed by Indonesia's government was at least 18 years old, and the retirement age was regulated in company regulations, cooperation agreements, or laws and regulations. These two aspects were stated in labor laws, No. 13, the year 2003, concerning employment. Moons et al., 2004, and Dalkey, 2002 in Nofitri, 2009 [14], stated that age was a factor that could affect the quality of life. Herawati and Sasana, 2013 [15], stated that a productive age resulted in higher productivity.

\section{Analysis of financial impact}

Based on Table 2, the results of the financial impact showed that male respondents dominate the decrease in income and the increase in expenditure. It is in line with Miles's theory et al., 1992 [16], stating that men experienced stress more easily than women, which hindered their ability to manage finances.

Based on Table 2, the largest decrease in income and an increase in expenditure, based on the age of health workers, were experienced by elderly respondents. Solihah, 2013 [17], expressed the opinion in her research that as you entered adulthood, one's financial management would decrease. It is in line with the results of this study.

Based on the data in Table 3, there was a decrease in average income and an increase in the average expenditure of health workers during the COVID-19 pandemic. The average decrease in income experienced by respondents was IDR $1,106,793 \pm 2,473,370$. Meanwhile, the average increase in expenditure experienced by respondents was IDR $1,144,701 \pm 841,336$. It indicated that respondents experienced more significant expenditure than their income.

A comparison of average income was analyzed by calculating the difference in the amount of income before and during the pandemic from each respondent with a simple mathematical formula. The results were totaled and analyzed descriptively to calculate the average value. The two variables were then analyzed statistically to determine the significance of the decrease in income experienced by the health workers before and during the pandemic.

The descriptive analysis resulted in an average decrease in income of IDR 1,106,793 \pm $2,473,370$. The normality test was then carried out using the Kolmogorov-Smirnov test, and the results were $p=0.000$ or $p<0.05$. Based on these results, the test data distribution was not normal; thus, the Wilcoxon signed-ranks test was applied to identify the test data significance. The Wilcoxon signed-ranks test obtained $p=0.000$ or $p<0.05$, indicating that health workers experienced a significant decrease in income.

Based on Table 4, all respondents still worked and earned a salary. In addition, there was a decrease in the number of respondents who 
opened businesses and practices due to a decrease in business practice. The decrease of respondents who opened a business or private practice could be one of the reasons of the decline in average monthly income of health workers.

A comparison of average expenditure was carried out by calculating the difference in total expenditure before and during the pandemic with a simple mathematical formula. The results were then analyzed by descriptive analysis to calculate the average value of the respondents' increase in expenditure. Furthermore, the two variables were analyzed using statistical analysis to identify their significance.

Based on the results of descriptive analysis, the average increase in expenditure was IDR $1,144,701 \pm 1,841,336$. Then, the normality test was carried out with the Kolmogorov-Smirnov test, and the result was $p=0.000$ or $p<0.05$. Based on the result, the data distribution was not normal; thus, the Wilcoxon signed-ranks test was needed to identify the data test's significance. The Wilcoxon signed-ranks test resulted in $p=0.000$ or $p<0.05$, indicating that health workers experienced a significant increase in expenditure.

Based on Table 5, the majority of respondents experienced dominant changes in expenditures for health needs, foodstuffs, processed food/beverages, and phone credit/data package. Changes in costs incurred to fulfill these needs could be a factor in the increase in health workers' average monthly expenditure. Some respondents experienced changes in spending on electricity, fuel oil, and public transportation as the family members reduced their outside activities and preferred to stay at home. Thus, the expenditure spent on electricity needs increased.

Based on Table 6, most respondents had difficulty in fulfilling the need for credit installments followed by the cost of health insurance. Some respondents had difficulty in fulfilling employee salaries and providing holiday allowance such as Tunjangan Hari Raya, company maintenance costs, education costs, phone credits/data packages, and medical devices. Nevertheless, some respondents did not experience difficulties in fulfilling their needs.

Based on the data in Table 7, the majority of respondents did not take any action. It could be because the respondents still received income from their salaries. Some respondents cut employee salaries, used savings, and proposed relaxation of credit payments.

It is important to note the limitations of our study. Even though it involves all provinces in Indonesia, the number of respondents is still limited. It is better if the number of respondents is more so that the data are more varied.

\section{Conclusion}

During the COVID-19 pandemic, health workers experienced a decrease in productivity in the form of a significant decrease in income and a significant increase in expenditure. There was a decrease in the number of respondents who opened businesses, and most respondents experienced dominant changes in expenditures for health needs.

\section{References}

1. Van Bavel JJ, Baicker K, Boggio PS, Capraro V, Cichocka A Cikara $\mathrm{M}$, et al. Using social and behavioural science to support COVID-19 pandemic response. Nature Human Behaviour. 2020;4(5):460-471. https://doi.org/10.1038/s41562-020-0884-z PMid:32355299

2. Task Force for the Acceleration of Handling Coronavirus Disease 2019 Republic of Indonesia. Distribution Map (Peta Sebaran) on 14 May; 2020. Available from: https://www.covid19.go.id. [Last accessed on 2020 May 15].

3. Ferguson N, Laydon D, Nedjati-Gilani G, Imai N, Ainslie K, Baguelin $\mathrm{M}$, et al. Report 9: Impact of non-pharmaceutical interventions (NPIs) to reduce COVID19 mortality and healthcare demand. Imperial College London. 2020;10:77482. https://doi.org/10.25561/77482

4. Anderson RM, Heesterbeek H, Klinkenberg D, Hollingsworth TD. How will country-based mitigation measures influence the course of the COVID-19 epidemic? Lancet. 2020;395(10228):931-4. https://doi.org/10.1016/S0140-6736(20)30567-5 PMid:32164834

5. Yunus NR, Rezki A. Lock down policy as a precaution against the spread of the corona virus Covid-19. Salam. 2020:7(3):22738. https://doi.org/10.15408/sjsbs.v7i3.15083

6. Susilo A, Rumende CM, Pitoyo CW, Santoso WD, Yulianti $\mathrm{M}$, Herikurniawan $\mathrm{H}$, et al. Coronavirus disease 2019: Overview recent literature. J Penyakit Dalam Indonesia. 2020;7(1):45-67

7. Willan J, King AJ, Jeffery K, Bienz N. Challenges for NHS hospitals during covid-19 epidemic. BMJ. 2020;368:m1117. https://doi.org/10.1136/bmj.m1117

PMid:32198166

8. Ministry of Health Republic of Indonesia. Pedoman Penerapan Kajian Farmakoekonomi. Jakarta: Ministry of Health Republic of Indonesia; 2013.

9. Sugiyono S. Metode Penelitian Kuantitatif dan Kualitatif dan R and D. Bandung: Alfabeta; 2010.

10. Suharsimi A. Prosedur Penelitian Suatu Pendekatan Praktik. Jakarta: Rineka Cipta; 2006

11. Ghozali I. Multivariate Analysis Application with IBM SPSS 23 Semarang: Diponegoro University Publishing Agency; 2016.

12. Sutrisno E. Human Resource Management. $1^{\text {st }}$ ed. Jakarta: Kencana Prenada Media Group; 2009.

13. Nur A, Pradekso T, Setyabudi D, Herieningsih SW, Surrayya N. Effect of age, education level, and gender on media consumption behavior. Interaksi Online. 2014;2(4):1-11.

14. Nofitri NF. Gambaran Kualitas Hidup Penduduk Dewasa Pada Lima Wilayah di Jakarta. (Unpublished Thesis). University of Indonesia, Depok, Indonesia; 2009. 
15. Herawati N, Sasana H. Analisis Pengaruh Pendidikan, Upah Pengalaman Kerja, Jenis Kelamin dan Umur Terhadap Produktivitas Tenaga Kerja Industri Shutllecock Kota Tegal. (Doctoral Dissertation). Semarang, Indonesia: Faculty of Economic and Business; 2013.
16. Miles MB, Huberman AM. Analisis Data Kualitatif. Jakarta: UI Press; 1992.

17. Sholihah FV. Manajemen Sumber Daya Keluarga dan Ketahanan Keluarga Lanjut Usia. (Unpublished Thesis). Bogor, Indonesia: Bogor Agricultural Institute; 2013. 